\title{
Comments
}

\section{SEX DISCRIMINATION: THE TEXTBOOK CASE}

A few years after Brown v. Board of Education ${ }^{1}$ had been decided and long before it was even partially implemented, a large-circulation, popular magazine suggested in an editorial that the way to ease white Southern anxiety about and resistance to racial desegregation was to resegregate the schools along sex lines. ${ }^{2}$ The writer argued that Southerners were most worried about the possibility of interracial romance; sex segregation would prevent this and reduce juvenile delinquency as well. There would be no added expense caused by maintaining two parallel school systems because the South had long maintained two systems. And lest anyone think that the Supreme Court would find that sexually segregated education was also inherently unequal, the writer pointed out that separate education for boys and girls had a long and honored tradition in America. ${ }^{3}$

In 1969 a federal district court in Louisiana upheld a racial desegregation plan which included temporary, partial segregation by sex. ${ }^{4}$ The court asserted that "Many school districts in this country have long operated separate schools for boys and girls" and that to do so was constitutionally acceptable. ${ }^{5}$ Although no public school districts were actually operating separate systems for boys and girls, ${ }^{0}$ in a sense the court was correct. In effect, the entire country has been operating separate systems for boys and girls despite the fact that they usually share classrooms. Not only are classes always lined up in two lines with boys in one and girls in the other, but teachers and other educators also have different expectations about the interests and abilities of individual children based largely on the sex of the child. For example, teachers expect boys to be "more difficult," and to have more difficulty learning to read, to be interested in science and

1. 347 U.S. 483 (1954).

2. Editorial: Segregation by Sex Might Ease Fears of Racial Intermarriage, 231 Saturday Evening Post 10 (Dec. 6, 1958).

3. Id.

4. Moore v. Tangipahoa Parish School Bd., 304 F. Supp. 244 (E.D. La. 1969). The sex segregation aspects of the plan were challenged only on the basis that they were racially motivated. The court disagreed.

5. Id. Contra, Smith v. Concordia Parish School Bd., Civil Action No. 11-577 (W.D. La. 1970) (resegregation by sex invalid because racially motivated).

6. Editorial: Segregation by Sex Might Ease Fears of Racial Intermarriage, 231 Saturday EVEning Post 10 (Dec. 6, 1958). 
building, to be active; they expect girls to be inore docile, interested in domestic tasks, and easily consigned to passivity. ${ }^{7}$

The impact of the double curriculum is to teach girls to have a very different view of theinselves from that which boys are encouraged to have. The schools, in short, take a very active part in socializing children to accept traditional sex role stereotypes. Even twenty years after Brown, black children continue to be treated differently froin whites, often in very subtle and unconscious ways. The difference between that inequality and the distinction based on sex is that vast numbers of educators and courts believe that racial inequality is wrong and ought to be eradicated but that equality is to be measured as between boys of the two races or as between girls-inequaity between the sexes is not troublesome.

Many articles have been written about sex differences in education based on a set of unquestioned assumptions: boys and girls have very different ability to learn; they will learn froin different kinds of materials; they are to be prepared for different and mutually exclusive roles; girls are limited by their sex to domestic tasks and whatever they are taught ought to be kept in that context; boys are too active and too intellectual for domestic tasks, will be bored by them, and must be challenged by exciting and adventurous lessons. ${ }^{8}$ In other words, the education of boys and girls should be, must be, unequal.

After Brown, however, and a number of cases holding that black and white students must be treated the same once admitted to the same schools, ${ }^{9}$ it seems likely that it will be hard to justify different educational content assigned on the basis of sex. This is especially true because the unquestioned assumptions set out above amount to a firm belief in female inferiority and this is the lesson taught to both boys and girls: girls grow up to be mommies, never anything else; mommies are boring, stupid servants who never do anything but cook and clean. ${ }^{10}$ A number of laws have been passed ${ }^{11}$ and cases decided ${ }^{12}$

7. Cf. Sex Differences in the Elementary Schools: $A$ Discussion, 46 NAT'L ELEMENTARY PRINCIPaL, No. 2, 8 (Nov. 1966).

8. Several such articles appear in 46 NAT'L Elementary Princrpal, No. 2 (Nov. 1966); the entire issue is devoted to learning differences between boys and girls. The issue is infused with the premises stated in the text although none of the authors seeins to have noticed it. The authors seem concerned almost exclusively with finding ways of inproving the school environment for boys. See also Waite, Blom, Zimet, \& Edge, First-grade Reading Textbooks, 67 The Elementary School J. 366 (1967).

9. McLaurin v. Oklahoma State Regents, 339 U.S. 637 (1950); Sweatt v. Painter, 339 U.S. 629 (1950); Sipuel v. Bd. of Regents, 332 U.S. 631 (1948); Missouri ex rel. Gaines v. Canada, 305 U.S. 337 (1938).

10. E.g., N. Frazier \& M. SAdKer, SeXISM IN Schoor aNd Society, ch. 5, 76-113 (1973); Stewig \& Higgs, Girls Grow Up to Be Mommies: A Study of Sexism in Children's Literature, 98 LIBRARY J. 236 (1973). 
in recent years supporting equality between the sexes. For the most part these laws have to do with the rights of adult women to be treated the same as adult men. Even Title IX of the Education Amendinents of 1972 forbidding sex discrimination in educational institutions receiving federal funding was apparently passed because of Congressional concern, not with elementary schools or curriculum content, but with higher education admissions policies (although certaim exceptions were made with regard to college admissions), and with employment, pay and promotional opportunities of women faculty and staff. ${ }^{13}$ The shortcoming of these laws is that they apply to women after it is already too late. Long before adulthood, women (and men) have been so socialized into their rigid roles and into a belief in female inferiority ${ }^{14}$ that the effects of early childhood discrimination cannot be overcome by mandates for equal treatment in adulthood. ${ }^{15}$

This Comment will document the extent of sex role stereotyping in textbooks used in public schools, because these are the core of the curriculum and the most tangible medium for conveying the message; report on several efforts to counteract the effects of these books or obtain the adoption of better ones; and finally comment on the effectiveness of these efforts and the necessity for more drastic action to achieve equality.

\section{I}

The public schools play a very important part in the process of socialization ${ }^{16}$ and the message they provide is precisely that women are inferior to men, that they are restricted by their sex to very dull,

11. E.g., The Equal Pay Act of 1963, 29 U.S.C.A. $\$ 206$ (d); Title VII of the Civil Rights Act of 1964, 42 U.S.C.A. $₹ 2000 \mathrm{e}-2$ (a) (1). (1971).

12. Frontiero v. Richardson, 411 U.S. 677 (1973); Reed v. Reed, 404 U.S. 71

13. P.L. 92-318 Legislative History, 1972 U.S. CODE CoNa. \& AD. News 2511.

14. E.P. Torrance, Guming Creative Talent 112 (1962); E.P. Torrance, SelfConcepts and Their Significance in the Learning and Adjustment of College Freshmen 109 (unpublislied doctoral dissertation, University of Michigan 1951); Broverman, Vogel, Broverman, Clarkson, \& Rosenkrantz, Sex-Role Stereotypes: A Current Appraisal, $28 \mathrm{~J}$. Social Issues, No. 2, 59 (1972); Brown, Sex-Role Preference in Young Children, 70 Psychological Monographs, No. 421 (1956); Hartley, Clildren's Concepts of Male and Female Roles, 6 MerriLL-PaLmer Q. 83 (1960); Rosenkrantz, Vogel, Bee, Broverman, \& Broverman, Sex-Role Stereotypes and Self-Concepts in College Students, $32 \mathrm{~J}$. Consulting Psychology 287 (1968).

15. Cf., Maccoby, Sex Differences in Intellectual Functioning in THE DevelopMENT OF SEX DIFFERENCES 25, (E. Maccoby ed. 1966); Horner, Toward an Understanding of Achievement-Related Conflicts in Women, 28 J. Social Issues, No. 2, 157 (1972).

16. Making the Female Mind Feminine, 103 ScIeNce News 86 (1973); Minuchin, Sex Differences in Children: Research Findings in an Educational Context, 46 NaT'L Elementary PrinctPal, No. 2, 45 (Nov. 1966). 
uninteresting personalities and lives, that they have no intelligence or spunk, that they are meant to serve men. ${ }^{17}$ Textbooks used in public schools are an important vehicle for inculcation of sex roles. They

17. Throughout this section I will be summarizing material found in a number of sources. It seems useful to set out the entire bibliography here.

Education for Survival: Schools and Sex Role Stereotypes, The National Education Association Conference on Sexism (S. McCune ed. 1972).

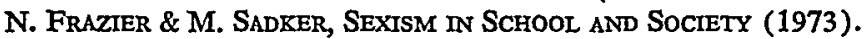

J. HOLE \& E. LEVINE, REBIRTH OF FEMINISM 333-37 (1971).

R. Rosenthal \& L. Jacobson, Pygmalion in the Classroom: Teacher ExpectaTION AND PUPIS' INTELlectual DeVElopMent (1968).

G. SEWARD, Sex aNd the Soclal Order (1946).

Women on Words and Images, Dick and Jane as Victims: Sex Stereotyping IN CHILDREN's READERS (1972).

Maccoby, Sex Differences in Intellectual Functioning, in ThE DEVELOPMENT OF Sex DifFerences 25 (E. Maccoby ed. 1966).

U'Ren, The Image of Woman in Textbooks, in WoMAN IN SexIST SOCIETY 218 (V. Gornick \& B. Moran eds. 1971).

California Advisory Commission on the Status of Women, California Women, 3940 (1971).

J. Jacobs, Committee to Study Sex Discrimination in the Kalamazoo Public Schools, Complaint to the U.S. Dep't of H.E.W., and Preliminary Findings of the Committee to Study Sex Discrimination in the Kalamazoo Public Schools (May 29, 1973).

J. Jeffrey and B. Craft, Committee to Study Sex Discrimination in the Kalamazoo Public Schools, Report of the Elementary Seliool Textbooks Task Force (1973).

Legal and Factual Analysis Committee of the Curriculum Development and Supplemental Materials Commission (California), Report (Nov. 2, 1973).

Scott, Foresman and Company, Guidelines for Improving the Image of Women in Textbooks (1972) (internal paper).

Sexual Stereotyping Subcomm. of the Legal and Factual Analysis Taskforce (California Curriculum Commission), Report (1973).

Statement of Allene Dietricl of the Committee to Study Sex Discrimination in the Kalamazoo, Michigan, Public Schools, Hearings on H.R. 208 Before the Subcomm. on Equal Employment Opportunities of the House Comm. on Education and Labor, 93d Cong., 1st Sess., pt. 1, at 462 (1973).

D. Ushio, Legal and Factual Analysis Committee of the Curriculum Development and Supplemental Materials Commission (California), Minority Position Paper (Nov. 29, 1973).

Note, Teaching Woman Her Place: The Role of Public Education in the Development of Sex Roles, 24 Hastings L.J. 1191 (1973).

Ahlum \& Fralley, Feminist Resources for Schools, 98 LiBRARY J. 234 (1973).

Blom, Waite \& Zimet, Content of First-Grade Reading Books, 21 THE READING TEACHER 317 (Jan. 1968).

Broderick, Creativity in Children: Some Case Studies, 46 NAT'L ELEMENTARY Principal, No. 2, 18 (Nov. 1966).

Chase, Sexism in Textbooks?, 90 Nation's Schools, No. 6, 31 (Dec. 1972).

Child, Potter \& Levine, Children's Textbooks and Personality Development: An Exploration in The Social Psychology of Education, 60 PsYchologicar MONOGRAPHS, No. 279 (1946).

Feminists on Children's Literature, A Feminist Look at Children's Books, 96 LIBRARY J. 235 (1971).

Frasher \& Walker, Sex Roles in Early Reading Textbooks, 25 THE REAdiNG TEACHER 741 (1972).

Frisof, Textbooks and Channeling, 1 WoMen: A J. of LIBERATION 26 (Fall 1969). 
provide the core of the curriculum and teachers rely on them heavily. Because they are printed, they have a forceful impact on the children. And they consistently provide the same image of males and females. Males are strong, active, adventurous; females are weak, passive, timid. This is true of reading books, ${ }^{18}$ arithmetic books, ${ }^{10}$ social studies books; ${ }^{20}$ it is true regardless of publisher, ${ }^{21}$ age of children for whom the books are intended, ${ }^{22}$ or era $\mathrm{m}$ which produced. ${ }^{23}$

There are really three ways in which the treatment of women in these books is objectionable. First, females are almost invisible; sec-

Heyn, Children's Books, 1 Women: A J. of Liberation 22 (Fall 1969).

Hollingworth, Social Devices for Impelling Women to Bear and Rear Children, 22 AM. J. Soc. 19 (1916).

Howe, Sexual Stereotypes Start Early, 54 SaTURday Rev. 76 (October 16, 1971).

Key, Male \& Female in Children's Books-Dispelling All Doubts, 56 AM. TEACHER, No. 6, 16 (Feb. 1972).

Kidd, "Now You See," said Mark, NEw YoRk REVIEw of Books, 35 September 3, 1970 (letter to the editors).

Kraft, Lost Herstory, The Treatment of Women in Children's Encyclopedias, $98 \mathrm{Lr}-$ BRARY J. 218 (1973).

Lewis, What the Publishers are Doing About Sexism in Textbooks, 90 TEACHER, No. 2, 52 (Oct. 1972).

Lyles, Grouping By Sex, 46 Nat'L Elementary Principal, No. 2, 38 (Nov. 1966).

Making the Female Mind Feminine, 103 SCIENCE News 86 (1973).

Minuchin, Sex Differences in Children: Research Findings in an Educational Context, 46 NAT'L Elementary PRINCIPAL, No. 2, 45 (Nov. 1966).

Nilsen, Women in Children's Literature, 32 College ENGLISH 918 (1971).

Sex Differences in the Elementary Schools: A Discussion, 46 NAT'L ElEmENTARY Princtipal, No. 2,8 (Nov. 1966).

Stewig \& Higgs, Girls Grow Up to Be Mommies: A Study of Sexism in Children's Literature, 98 LIBRARY J. 236 (1973). (1971).

Trecker, Women in U.S. History Higlt School Textbooks, 35 Socinl EducatTon 249

Waite, Blom, Zimet \& Edge, First-Grade Reading Textbooks, 67 THE ElEMENTARX ScHOOL J. 366 (1967).

Weitzman, Eifler, Hokada, \& Ross, Sex-Role Socialization in Picture Books for Prescliool Children, 77 AM. J. Soc. 1125 (1972).

Wiik, The Sexual Bias of Textbook Literature, 62 ENGLisH J. 224 (1973).

18. U'Ren, The Image of Woman in Textbooks, in WoMAN IN SEXIST SocIeTY 218 (V. Gornick \& R. Moran eds. 1971).

19. N. Frazier \& M. Sadker, Sexism in School aNd Society 102-03 (1973).

20. Women on Words and Images, Dick and JaNe as Victims: Sex StereotypING IN ChILdReN's Readers $44-45$ (1972); Kraft, Lost Herstory, the Treatment of Women in Children's Encyclopedias, 98 LIBRARY J. 218 (1973).

21. WOMEN ON WORDS AND IMAGES, supra note 20, at 69-70.

22. Frasher \& Walker, Sex Roles in Early Reading Books, 25 The REadina TEACHER 741 (1972) (first and second grade readers); Trecker, Women in U.S. History High School Textbooks, 35 Social Education 249 (1971) (high school level); Wiik, The Sexual Bias in Textbook Literature, 62 ENGLISH J. 224 (1973) (junior high school level).

23. Child, Potter and Levine, Children's Textbooks and Personality Development: An Exploration in The Social Psychology of Education, 60 Psychologrcal MonoGRAPHS, No. 279 (1946). 
ond, they appear only in stereotyped roles; and third, they are invariably scorned as inferior beings.

\section{A. Invisibility}

An analysis of children's textbooks done in 1946 found that only $28 \%$ of the characters in the books were female. ${ }^{24}$ The same percentages are still applicable today. ${ }^{25}$ In one series the pronouns "he," "him," and "his" appear in the first book but the pronouns "she," "her," and "hers" do not appear until the third; this series puts "boys," "him," and "man" in the basic vocabulary but "girls," "lier," and "woinan" in the supplemental vocabulary. ${ }^{26}$ In social studies books there are many biographies of inen but very few of women. ${ }^{27}$ Participants in the women's movement of the 19th century and other female public figures are left out almost entirely. ${ }^{28}$ A fourth grade science book shows seventeen occupations for inen; the only female shown is hanging clothes out to dry. ${ }^{29}$ Another science book includes thirty-nine men, most of them scientists; the only two women shown are observers, one watching Ben Franklin, the other merely a housewife. ${ }^{30}$

The impression children will derive from the absence of females in their books can easily be inferred. Women and girls play almost no role at all in life. When they do appear, they are observers, not participants. $^{31}$ Although it might be argued that inen do appear more in public life than woinen, the vast majority of the stories, arithmetic problems, etc. are about people in their everyday lives. ${ }^{32}$ The implication of the invisibility of women, then, is that only males are worth writing about, that females are extremely unimportant.

One justification put forward by some educators for the greater emphasis on male characters is that boys have more trouble learning to read and therefore the stories should be easier for them to identify with in order to encourage them to take an interest in reading. ${ }^{33}$ The re-

24. Id. at 9, n.7.

25. WOMEN ON WORDS AND IMAGES, supra note 20, at 69-70.

26. Statement of Allene Dietrich of the Committee to Study Sex Discrimination in the Kalamazoo, Michigan, Public Schools, Hearings on H.R. 208 Before the Subcomm. on Equal Employment Opportunities of the House Comm. on Education and Labor, 93d Cong., 1st Sess., pt. 1, at 466 (1973) [hereinafter cited as Dietrich stateinent].

27. WOMEN ON WordS AND IMAGES, supra note 20, at 71-72.

28. Id.; FRAZIER \& SADKER, supra note 19, at 101-02; Trecker, supra note 22.

29. Dietrich statement, supra note 26 , at 463.

30. Id.

31. Frazier \& Sadker, supra note 19, at 104; Women on Words and IMages, $\left.s u_{i}\right) r a$ note 20 , at 26 .

32. Child, Potter \& Levine, supra note 23 , at 49.

33. E.g., Waite, Blom, Zimet \& Edge, supra note 8, at 372-73. It is a standard 
verse justification has been used for greater emphasis on male characters in science and inath books: boys do better in science and math and are more interested in it, therefore they should be featured in science and math books. ${ }^{34}$.One very successful children's book with a female main character, Island of the Blue Dolphins, was almost rejected by the publisher when the author refused to change the main character to a male. ${ }^{35}$ As the success of this book has shown and some publishers have admitted, ${ }^{36}$ if stories about girls were more interesting, boys would be interested in them too.

Perhaps the real explanation for the invisibility of females in textbooks is that educators are primarily concerned about the education and educational success of boys. Educational publications which concentrate heavily on why Johnny can't read but Janey can and how to improve schools for all the Johnnys of the world ${ }^{37}$ make this one-sided concern obvious. The schools and the texts have also been criticized for being too "feminine"38 and thus making it difficult for boys to do well in school. It is not unlikely that this same motive is responsible for the disproportionate representation of males in textbooks.

\section{B. Stereotyping}

A 1946 analysis of children's books ${ }^{39}$ looked at the kinds of motivational training being given children through the books; it did not start out as a study of sex role indoctrination. After analyzing the kinds of behavior shown in the books, however, the authors concluded:

Perhaps the most striking single finding of this study is the extent to which a differentiation is made between the roles of male and female in the context of these readers.

bit of advice in creative writing courses and the publishing world that children's books should be about boys because girls will read about boys or girls but boys will only read about boys. Lewis, What the Publishers are Doing About Sexism in Tcxtbooks, 90 TEACHER, No. 2, 52 (Oct. 1972); Nilsen, Women in Children's Litcrature, 32 ColdeoB ENGLISH 918 (1971).

34. Nilsen, supra note 33 , at 925 .

35. Id. at 918 .

36. Lewis, supra note 33. And see Wiik, supra note 22, for a description of the response of a seventh grade class, all boys, to the story of Anne Frank.

37. For example the entire issue of 46 NAT'L Elementary PrIncipal No. 2 (Nov. 1966) was devoted to sex differences in education and was directed almost entirely to the problein of improving the education of boys.

38. E.g., Goldman \& May, Males: A Minority Group in the Classroom, $3 \mathrm{~J}$. or LEARNING DisabIIITIES 276 (1970); McFarland, Are Girls Really Smarter?, 70 THE ELEMENTARY SCHOOL J. 14 (1969); Palardy, For Johnny's Reading Sake, 22 The READINo TeAcher 720 (1969); Sexton, Schools Are Emasculating Our Boys, 48 SATURDaY Rev. 57 (June 19, 1965). Schools need to be changed so that boys can read better; what happens to girls is no concern of anyone's.

39. Child, Potter \& Levine, supra note 23. 
... [A] distinotion in role is being made between the sexes which may indeed have a certain validity as of our society of the present time, but which seems much more a survival of former practices. ${ }^{40}$

They found that females were shown as relatively helpless, ${ }^{41}$ "sociable, kind and timid, but inactive, unambitious and uncreative."t2 Further, persons who supplied information to central characters were predominantly male even among unrelated adults, though the most important unrelated adults who supply knowledge to children in real life are their teachers, most of whom are women. "Males, in short, are portrayed as the bearers of knowledge and wisdom, and as the persons through whoin knowledge can coine to the child."43

Recent studies have found that the same pattern is still present to the same degree as thirty years ago. ${ }^{44}$ Nearly all the adult women shown in children's textbooks are stay-at-home mothers perpetually wearing their aprons over their 1950's-length dresses. In addition, these women are not only exclusively mothers, but also, as such, they never do anything but cook and clean. They do not play with the children, teach them things, read books, or in any way step out of the role of servant. They never know the answers to their children's questions; they must ask Father.

In some rare instances women are shown outside the role of mother. For example, a story about the Curies is included in a book in use in California. Madame Curie is pictured as a lab assistant looking over the shoulder of her husband and another man, probably the inan who in real life was her lab assistant. ${ }^{45}$ In a story about scientists there are seven male scientists all shown working on independent

\section{Id. at $46-48$.}

41. Id. at 48 .

42. Id. at 47 .

43. Id. at 48. This finding suggests a possible alternative explanation of boys' learning difficulties: boys have been taught even by the time they enter school and are told by their books that females are not worthy of respect, cannot be authority figures, and have no knowledge to give them (girls have been taught to defer to everyone). Most teachers are female; their task is practically impossible because the very books out of which they seek to teach reading tell the boys that the teachers, because they are female, cannot teach thein anything. Until children are taught that both males and females are worthy of respect as human beings and are capable of being authoritative, boys will have trouble learning from female teachers.

It has also been suggested that the development of creative potential requires both sensitivity (allowed only to females) and independence (allowed only to males) so that sex role stereotyping inhibits creative development in both boys and girls. E.P. ToRrance, Guding Creative Talent 111 (1962). Here again, the author is concerned about the effect on boys, but believes sex roles must be deemphasized in order for boys to do well. Id. at 154.

44. U'Ren, supra note 18.

45. U'Ren, supra note 18 , at 222. 
projects of their own design; the one female scientist shown, the story quickly points out, is working on a project which "is not her own idea," it was assigned to her by the company she works for. ${ }^{40}$ That is, when women are not being Mother, they still do not have any ideas of their own and are still subordinate. They are shown only rarely in occupations, in very few different ones, and never acting autonomously. ${ }^{47}$ The teachers editions of these books suggest uses for them which further reinforce the stereotypes. Thus the manual accompanying the Dick and Jane series suggests that teachers introduce Mother by saying, "Dick, Jane, and Sally's mother is like your mother. She takes care of the house and the children." 48

In 1969 California adopted a replacement for the Dick and Jane series the main characters of which are Mark and Janet and Mother and Father. ${ }^{49}$ Apparently only the names have been changed. Mother is still wearing high heels and dresses from another era; she never does anything but wait on her husband and children; she never knows anything; she never exchanges more than one sentence with Father in 410 pages. ${ }^{50}$

Female children in these books are well prepared to enter the world of adult women. They are subordinate not only to their parents but also to their male siblings, ${ }^{51}$ who are always older and bigger than they. Again, the teachers manual gives suggestions which reinforce the stereotypes. Concerning a story in which a boy and a girl are bathing a dog together, the manual comments: "Boy-like, Dick occupies the center of the stage in a situation where, as Spot's master, he obviously feels he is in charge."52 Girls are always either observing and admiring boys or playing quietly with dolls and kitchenware. In arithmetic problems, girls are always sewing, cooking, or shopping while boys are shown solving problems in a wide variety of contexts never including domesticity. ${ }^{53}$ A "health" book tells the children (sixth graders), "Unfortunately, every boy can't be a leader of men, and every girl can't be a belle of the ball." "54 Thus is realism defined.

\section{Id.}

47. Id.; WOMEN ON WORDS AND IMAGES, supra note 20, at 73-74.

48. Quoted in Frasher \& Walker, supra note 22, at 746. The implications of this statement are really overwhelming: it makes children seem hittle more than fixtures of the house like mothers; and what does it say to children in the class whose mothers perhaps do not stay home and "take care of the house and the children."

49. Basic Reading Program, Harper and Row (1969).

50. Kidd, "Now You See," said Mark, NEW YORK REvrew of Books, 35 September 3, 1970 (letter to the editors).

51. U'Ren, supra note 18, at 219.

52. Quoted in Frasher \& Walker, supra note 22, at 745.

53. FRAZIER \& SADKER, supra note 19, at 102.

54. Dietrich statement, supra note 26 , at 463 . A sentence to make grammarians as well as egahtarians shudder. 
One series of stories centers around a boy buying a doll and being very embarrassed about carrying it home. He does not want to be seen with it and has only bought it to trade to a girl for her printing press on which he imtends to publish his own newspaper. One commentator noted:

The strangest aspect of this group of stories was that the girl had originally asked for and received the press from a store giving it away. One wondered what she intended to do with it, if anything. At no time did she use it in the stories, nor even show that she knew how it worked. Instead, she was shown sitting and watching while the boy operated it. ${ }^{55}$

Probably she only asked for it because, like all females, she was greedy. ${ }^{56}$

It has been suggested that "woinen's comparatively low achievement . . . is oaused by cultural conditioning from childhood on" as well as by discrimination in adulthood. ${ }^{57}$ School textbooks, by stereotyping female sex roles, help establish in girls the very limited expectations that society allows them to lave for themselves. The series analyzed by Child ${ }^{58}$ included 112 instances of achievernent by boys, only 24 by girls. The boys' achievement concerned personal advancement 81 times, helping others 28 times and intellectual achievement 3 times. The girls achieved by helping others 18 times and in personal advancement 6 times. They did nothing intellectual at all. ${ }^{59}$ More recent books perpetuate these images. For example, archeologists are defimed as "men who dig" and a predominantly female Red Cross unit is referred to, because they are all related, as "brothers." Dictionaries giving examples of word usage are the same: "Study: Joseph is studying to be a doctor. Her constant study is to please her parents. Steep: She steeped the tea in boiling water. Professor Jones steeps himself in Latin." 61

55. Frasher \& Walker, supra note 22 , at 745 .

56. See text accompanying notes 65-79 infra.

57. Ferguson, Response to Mr. Gleason, 32 College ENGLish 931, 932 (1971).

58. Supra note 23.

59. Id. at 14-15. Most of the achievements were rewarded, a few punished, but intellectual achievement was neither rewarded nor punished. The books are obviously inculcating other values in addition to sex roles, including anti-intellectualism. Kidd, supra note 50, goes into these other values in some detail as they appear in the 1969 Harper and Row series.

One of the functions of schools is, presumably, to socialize children. This function is limited by various constitutional guarantees, see text accompanying notes 159-191 infra. The import of the Child and Kidd studies is that, in addition to concerning ourselves with constitutional requirements such as racial and sexual neutrality, we would do well to reconsider the other values being taught in the schools. In addition to Child and Kidd, see the comments and suggestions in Worley, Developmental Task Situations in Stories, 21 The Reading Teacher 145, 148 (1967).

60. WOMEN ON WoRDS AND IMAGES, supra note 20 , at 30.

61. Dietrich statement, supra note 26 , at 463. 
The result is what one psychologist has called women's motive to avoid success. ${ }^{62}$ She reports that women develop much greater levels of anxiety as they approach success than appear in men and that women are actually motivated to avoid success because it does not comport with the image they have been taught to have of themselves.

Textbooks in their portrayal of females actively encourage girls to think of themselves as the present and future servants of their male classmates; "there is little to encourage them to acquire skills that could serve toward their personal advancement."

\section{Inferiority}

Stereotyping is often indistinguishable froin belittling women. However, there are those who claim that it is possible to stereotype females in traditional roles without degrading them because, although women are different they are equal and their role is an honorable one. ${ }^{64}$ Perhaps an examination of the ways in which textbooks heap opprobrium on their female readers through sex role stereotyping will show not only how offensive the books are but also how intimately related are the concepts of women's role and women's inferiority.

Females are portrayed as lazy twice as often in proportion to the number of appearances as males. ${ }^{65}$ Girls are shown as imcompetent, incapable of independent thought or direct action, quick to give up: "They collapse into tears, they betray secrets; they are more likely to act upon petty or selfish motives." ${ }^{16}$ In the series adopted in California in 1969 and still in use, there is an episode in which Janet is trying to skate and falls down. Her brother Mark is present and says to Mother, "She can not skate. I can help her. I want to help her.

62. Horner, Fail: Bright Women, 3 Psychology Today, No. 6, 36 (Nov. 1969).

63. Child, Potter \& Levine, supra note 23, at 17.

64. As Naoni Weisstein put it, "It is useless to talk about women being different but equal; all of the tests I can think of have a 'good' outcome and a 'bad' outcome. Women nsually end up at the 'bad' outcome." Weisstein, Psychology Constructs the Female, in WoMan IN SEXIST SocIETY 133, 144 (J. Gornick \& B. Moran eds. 1971), originally a paper delivered at Davis, Calif., at a meeting of the American Studies Association, October, 1968, under the title Kinder, Küche, Kirche as Scientific Law: Psychology Constructs the Female, also reprinted in Sisterhood is Powerful 205 (R. Morgan ed. 1970). And see Broverman, Broverman, Clarkson, Rosenkrantz \& Vogel, Sex-Role Stereotypes and Clinical Judgments of Mental Health, $34 \mathrm{~J}$. Consulting Psychology 1 (1970) reporting that different personality traits were assigned by clinicians to healthy males and liealthy females and that those assigned to males correlated to socially desirable traits as determined by other studies.

65. Child, Potter \& Levine, supra note 23, at 48; U'Ren, supra note 18, at 223. This coincides with the apparently still-popular notion that women do not want to be independent but prefer to "catch" lusbands so they can sit lome and do nothing all day while their liusbands support them.

66. U'Ren, supra note 18 , at 223. 
Look at her, Mother. Just look at her. She is just like a girl. She gives up." ${ }^{07}$ He helps her and then says, "Now you see. Now you can skate. But just with me to help you." ${ }^{8}$ Now you see-girls are helpless, incompetent, dependent creatures.

The books not only portray individual girls and women as having undesirable characteristics, but also invariably attribute these characteristics to the entire class of females as Mark does in referring his sister in the skating episode. A fifth grade reader carries the following "joke": "What is square and has bats in the belfry?' Dusty grinned. 'That's easy, Scruggs-girls!" "09 Another story shows a girl asking boys what they are doing and whether their activity is a secret; the boys reply, "[nt is no secret. We are willing to share our great thoughts with inankind. However, you happen to be a girl."7o Many stories show boys refusing to play with girls or accusing other boys of being like girls, the ultimate insult. ${ }^{71}$

Dictionaries also add to the portrayal of woinen as inferior. They specifically define "feminine," "womanly", and "womanish" as "like a woman, ... . weak." "Masculine," "inanly," and "manful" are defined as "like a man; . . . strong, vigorous, . . . brave, noble, independent and honorable." 72

Boys are often shown rescumg older females. One series shows a boy saving his family from a flood and thinking to himself that his mother and older sister had gone through the same thing: "And even if they were older, they were, after all, only women." Later in the story the boy is reported to feel much better once there is a grown man in the house, because "Women were always so excitable and nervous." I3 In another story Mother is unable to help her son down from a tree he has climbed; the child has to wait for Father to come home and get a ladder from the garage, a solution Mother apparently could not think up. ${ }^{74}$

In many cases female characters are shown as undesirable even

67. Reproduced in TrME, Nov. 5, 1973, at 66 (underscoring in original); reviewed in Kidd, supra note 50.

68. Kidd, supra note 50 , at 36 .

69. J. Jacobs, Committee to Study Sex Discrimination in the Kalamazoo Public Schools, Complaint to the U.S. Dep't of H.E.W., and Preliminary Findings of the Coinmittee to Study Sex Discrimination in the Kalamazoo Public Schools 2 (May 29, 1973).

70. J. Jeffrey and B. Craft, Committee to Study Sex Discrimination in the Kalamazoo Public Schools, Report of the Elementary School Textbooks Task Force 5 (1973). So much for the contention that the use of the masculine includes the feminine.

71. Dietrich statement, supra note 26 , at 466 .

72. Jeffrey \& Craft, supra note 70 , at 9.

73. Id. at 13 .

74. Id. 
when doing things for which male characters have been praised. One book in use in California shows a male as an admirable character for working hard and making a lot of money, the money apparently being for his own use. But a girl who is trying to earn money for herself is shown as a very negative example. ${ }^{75}$ Male characters are constantly maligning women and girls generally or telling specific females that they cannot do something boys can do, either because the boys do not want them around or because they "will get scared and cry."70 Books tell their female readers "Accept the fact that this is a man's world and learn how to play the game gracefully."77 Male characters are shown as concerned about what they will be as adults while females are only concerned about whom they will marry. ${ }^{78}$ The examples go on endlessly. ${ }^{79}$

Most of the criticisins of females are tied in with the presuinptions about female roles. Women are never anything but servants because they are inferior. They are unable to cope with life, that is why they have to have husbands to support them and elementaryschool-age sons to protect them. Their adult role is one-dimensional because they are too stupid to make anything of themselves.

Books adopted im California in 1974 still portray females as fearful, passive and stupid. The books have been revised somewhat to include representation of ethnic minorities; now instead of Mark and Janet being involved in the skating episode, we see the same comments about being "just like a girl" made by Pedro about his sister. In the old edition there is a story about Janet and a girl friend who are told by Janet's mother that they are not smart enough to write a book because they are just two hittle girls. Mother also tells them that she herself is not smart enough to think up a riddle. In the revised edition we find a black girl and an Asian girl being told the same things by the Asian girl's mother. The reviewer commented, "We have progressed from Anglo female morons to multi-ethmic female morons." 80

\section{Impact}

Not one of the writers on this subject, on any side of the issue, has questioned the presumption that textbooks affect the children in

75. U'Ren, supra note 18 , at 223.

76. Key, Male \& Female in Children's Books-Dispelling All Doubts, 56 AM. Teacher, No. 6, 16, 20 (Feb. 1972).

77. Quoted in Feminists on Children's Literature, A Feminist Look at Children's Books, 96 LIBRARY J. 235, 236 (1971).

78. Id. at 238. Key, supra note 76 , at 17.

79. WOMEN ON WORDS AND IMAGES, supra note 20, at 32-34, 64-68.

80. Sexual Stereotyping Subcomm. of the Legal and Factual Analysis Taskforce (Cal. Curriculum Commission), Report 2 (1973). 
their ability to perform academically and in their views of themselves and the world. Some writers have suggested that the books are too "pollyannish"s1 and therefore boys cannot identify with them, that they are too "feminine" and lack sex role differentiation which "conflicts with one of the primary developmental tasks that confront the first-grader, that of specifying, maintaining and reinforcing his own appropriate sex role." ${ }^{\text {2 }}$ They also suggest that the books may have "little value in encouraging a [male?] child to learn to read, partly because the books attempt to present stories for girls as well as boys." ${ }^{83}$ None of these critics has questioned the image of females being presented to the children; they apparently think it is accurate. But they have also made no effort to show that boys and girls really have different interests and cannot be taught to read from the same books. They make the presumption that boys will learn only if taught about something challenging like nuclear fission which girls cannot learn about, and that girls will learn only housewifely subjects. ${ }^{84}$

Some schools have actually separated the children by sex in order to improve the boys' academic progress. ${ }^{85}$ One such experiment was reportedly very successful; the boys did better academically and the girls were less jealous of each other. No mention is made of any. effect on the girls' academic performance, apparently a matter of indifference. ${ }^{86}$ The more striking thing about these experiments is that they are considered opportunities to enrich the curriculum for the boys. Boys are given more lessons in the context of science, building, transportation; girls have lessons revolving around cooking and sewing. ${ }^{87}$ On one typical day, boys had an activity involving playing with earthworms and making a chart of their experience; the girls spent the same time period preparing a party for the boys. ${ }^{88}$

81. Waite, Blom, Zimet \& Edge, supra note 8, at 367 . If by "pollyannish" the authors mean pseudo-cheerful or unrealistically cheerful, then other reviews support them, e.g. Kidd, supra note 50. But the characterization of this superficiality as "feminine" is certainly questionable. (The authors never state precisely what they classify as appropriate for boys or for girls nor on what basis they assume that six-year-olds' activities must be determined by sex.)

82. Waite, Blom, Zimet \& Edge, supra note 8, at 372.

83. Id. at 372-73. Other writers have found that these same books are dominated by male characters and consistently insult females. See Key, supra note 76, at 16 . Yet Waite, et al., seem to believe that girls can identify with these books or do not care that girls cannot, for they are only concerned with the inability of boys to do so.

84. Iyles, Grouping By Sex, 46 NaT'L Exementary Principal, No. 2, 38, 41 (Nov. 1966).

85. Id.; Sex Differences in the Elementary Schools: A Discussion, 46 NAT'L ELEmentary Principal, No. 2, 8 (Nov. 1966).

86. Lyles, supra note 84 .

87. Id. at 41.

88. Sex Differences in the Elementary Schools: A Discussion, supra note 85, at 10. Not only were the girls limited to a role-dictated activity, they were not even pre- 
These educators are directing all their energies and all the resources of the public schools to educating the boys while the girls are literally relegated to the kitchen. This division is given authority by the printed word in every book the children use whether they are in the same classroom or not. In addition, teachers very clearly have different expectations about their students and these expectations are accepted by the children themselves, affecting their performance in the classroom and later in life. ${ }^{80}$

Girls consistently do better academically than boys until high school. Educators explicitly believe that boys do less well in elementary school because the schools are too "feminine" but that girls do less well later on because they are not as smart as boys. ${ }^{00}$ Educators have even justified having higher standards for admission of girls to "academic" high schools than for boys on the basis that girls are not as smart as their elementary school grades indicate and will inevitably do less well in high school, while boys will do better. ${ }^{91}$

Perhaps the real reason girls do less well as they get older is that academic excellence is not part of their "appropriate sex role" as defined for them in their textbooks. They have been taught that girls and women are weak, stupid and incompetent, and that no male will marry a female who is sinarter than he. And they believe it; girls learn to fear success. ${ }^{92}$

In testimony before a subcommittee of the House Labor and Education Committee, a representative of the Kalamazoo, Michigan, committee commented that very little research has been done on the effect of sexist materials and that it is not really known whether, for example, the fact that only men are shown as doctors affects girls' aspirations. $^{93}$ Even with the limited research done so far, the conclusion seems inescapable that both boys and girls cannot help but be profoundly affected by the stereotyping in the books and especially by the constant building up of boys and disparagement of girls. Further, as

paring a party for themselves; inevitably they do things for the boys; they are always servants.

89. Frazier \& SADKER, supra note 19, at 137-40; Rosenthal \& JACOBSon, Pygmalion in the Classroom: Teacher Expectation and Pupils' Intellectual DEVELOPMENT (1968); TORRANCE, supra note 43, at 111-13.

90. Sex Differences in the Elementary Schools: A Discussion, supra note 85, and other articles in that issue of NAT'L ELEMENTARY PRINCIPAL.

91. But see Berkelman v. San Francisco Unified School Dist., 43 U.S.L.W. 2040 (9th Cir. July 1, 1974) rev'g Civil No. 73-1686 (N.D. Cal. 1973) (slip opinion), and rejecting this argument.

92. "Margaret Mead is quoted as saying ' $m a n$ is unsexed by failure, woman by success," Key, supra note 76, at 17 . The evidence that girls believe this sex-role ideology is abundant: see authorities cited in notes 14,15 , and 16 supra.

93. Dietrich statement, supra note 26 , at 469 . 
a matter of law and policy it seems clearly impermissible for the state, with or without evidence of adverse impact, to use materials which teach an entire class of students that they are, as a class, inferior, limited subhumans.

\section{II}

Efforts to eliminate sexism from public school textbooks, and the curriculum as a whole, have begun at various levels from privately funded groups, through local school districts to the state and federal governments. Some of these programs are directed specifically at the books; others are more general, such as the federal statute which prohibits sex discrimination in any educational institution receiving federal funds. ${ }^{94}$ As mentioned above, ${ }^{95}$ however, the legislative history indicates that Congress was concerned primarily about higher education and about discrimination in hiring rather than about the treatınent of students or the content of the curriculum.

At the state level, California has passed legislation requiring that textbooks portray women in a positive light and forbidding the use of books which treat woinen as inferior. ${ }^{96}$ Pennsylvania has a state constitutional amendment prohibiting sex discrimination and pursuant to that amendment the state Department of Education has issued a report, guidelines, and goals for eliminating sexism from the public schools. ${ }^{97}$

At the local level, the Berkeley Public Schools have instituted a women's studies program the purpose of which is to supplement textbooks with materials which portray women in a positive light and raise the issue of sex discrimination. The Kalamazoo, Michigan, school board created the Committee to Study Sex Discrimination in the Kalamazoo Public Schools. This group is also supposed to advise the board on the issue of sex discrimination in the schools. A similar committee exists in Ann Arbor, Michigan. ${ }^{98}$

94. Education Amendments of 1972, Title IX (20 U.S.C.A. $\$ \$ 1681-83$ ).

95. See, text at note 13 supra.

96. CaL. Educ. Code $\$ \S 9240,9243$ (West Supp. 1973).

97. Joint Task Force, Pennsylvania Department of Education, Sexism in Education (1972); Memoranda from the Pennsylvania Secretary of Education dated August 30, 1972, and Septeinber 5, 1972.

98. The Committee to Eliminate Sex Discrimination in the Public Schools and the Ann Arbor Chapter of N.O.W. have published An Action Proposal to Eliminate Sex Discrimination in the Ann Arbor Public Schools, a 16-page pamphlet; it was based on Marcia Federbush's Let Them Aspire: A Plea AND Proposal for Equalrty of OPportunity for Males and Females in the ANN Arbor Public Schools (1971). What effect this lias had is not known. Similar groups also exist in other cities including Minneapolis, Minn., Boulder, Colo., and Dayton, Ohio; see reports in 2 WoMEN's Studies NewsLetTer, No. 1, at 7, 12 (1974). 
Among private groups, there is an organization in San Francisco called Change for Children which provides in-service training for teachers in the public schools, maintains a library of nonsexist and feminist books and disseminates information about the problem. The National Education Association held a conference on sex discrimination in the public school curriculum in 1972 and has published some alternative curriculuun materials. ${ }^{92}$ A number of feminist organizations are developing non-sexist materials. ${ }^{100}$

\section{A. Federal Level}

Federal legislation, title IX of the Education Amendments of 1972, was passed in June 1972.101 Proposed regulations under Title IX were issued in June 1974:102 cominents on them are being accepted through October 15 and final regulations are not expected before the beginning of $1975 .{ }^{103}$ In their current version the regulations do not apply to textbooks or other curriculum materials because "the Department has concluded that specific regulatory provisions in this area would raise grave constitutional problems concerning the right of free speech under the First Amendment."104

No specifics have been given concerning whose first amendment rights are thought to be endangered. ${ }^{104 a}$ The textbook publishers are

99. Education for Survival: Schools and Sex Role Stereotypes, The NAtional Education Association Conference on Sexism (S. McCune ed. 1972) [hereinafter cited as EdUCATION FOR SURVIVAL].

100. Ahlum \& Fralley, Feminist Resources for Schools and Colleges: A Guide to Curricular Materials (1973) (contains a catalog) (available from the Clearinghouse on Women's Studies, SUNY, College at Old Westbury, Box 334, Old Westbury, New York, 11568).

101. 20 U.S.C.A. $\S \S 1681-83$.

102. 39 Fed. Reg. 22228 (1974).

103. San Francisco Chronicle, June 19, 1974, at 1, col. 8 (the regulations were announced to the press two days before they appeared in the Federal Register).

104. 39 Fed. Reg. 22230 (1974).

104a. This coinmentator wrote to the Secretary of Health, Education and Welfare in June and again in July asking for more specific information about the first amendment questions and in particular asking whose rights were involved. The Secretary responder in a letter dated October 7,1974, by saying:

I think it's clear that the First Amendment imposes restraints on Federal action restricting academic freedom, and for this reason we believe that the constitutional rights of educators, school administrators, and students in participating in the communication process, which is the very heart of education with regard to textbooks, must be observed.

[The letter goes on to say that the Department is nevertheless doing everything it can to eucourage voluutary revision of textbooks to eliminate sex bias from them.]

The Secretary uses the slogan "academic freedom" without explaining what he means by it and in a manner calculated to cloud the issues and forestall further analysis. The only thing that seems clear from his letter is, not that academic freedom requires federal noninterfereuce with choice of textbooks, but that the Secretary, relying on "academic 
said to be very concerned about their rights. ${ }^{105}$ The regulations, however, are directed at schools, school boards, and other government agencies, not at publishers. It is true that if schools are forced to adopt only nonsexist textbooks, publishers will not be able to sell books to schools unless they publish nonsexist books. It is also true that publishers who wish to sell to schools or any other government agency have always had to publish what those government agencies wanted to buy im order to make the sale; this fact has never been considered a violation of the publishers' first amendment rights. Although publishers may publisli whatever they choose, the government is not obligated to buy. And a publisher's having sold books to the government in the past does not create a vested right to continue selling books to the government; rather, the government is free to take its business elsewhere, especially if the former supplier can no longer meet the government's requirements.

There remain the schools and the students whose rights might be threatened by federal regulation of textbooks. The schools, as government agencies, are obligated by the Constitution not to discriminate ${ }^{106}$ and it is, at most, doubtful that they would have soine first amendment right to discriminate where books are concerned but not in other respects. As for the students, their first amendment rights are more likely being abridged by sex stereotyping. ${ }^{107}$

The first amendinent argument, then, appears to be little more than an excuse for not confronting what HEW admits is "a serious problem to which Title IX could well apply."108 Instead of regulation, the Department is offering to "increase its efforts, through the Office of Education, to provide research, assistance and guidance to local education agencies in eliminating sex bias from curricula and educational materials." 109 It should be noted, also, that even with regulations the penalty for noncompliance is withdrawal of the federal funding benefitting the offending school, ${ }^{110}$ a sanction rarely and reluctantly invoked by the federal government. ${ }^{111}$

The usefulness of Title IX im eliminating sexism in the schools depends, apparently, on the good will of HEW officials and the vigor

freedom" to justify his inaction, refuses to regulate according to the mandate of Congress. 1974.

105. Telephone conversation with J. Jacobs, from Kalamazoo, Mich., June 27,

106. See text accompanying notes 159-173 infra.

107. See text accompanying notes 174-189 infra.

108. 39 Fed. Reg. 22230 (1974).

109. Id.

110. Education Amendments of 1972, Title IX, 20 U.S.C.A. $\S \S 1681-83$.

111. K. Davidson, R. Ginsburg \& H. Kay, SeX-Based Discrimination In Family LAW 872 (1974). 
with which they intend to require compliance. The extent to which one can rely on these factors may be gauged by the fate of the onc complaint filed about textbooks. It has been awaiting action simce May $1973,{ }^{112}$ and if the final regulations do not cover textbook content, no action will be taken on this complaint and no remedy will be available under Title IX. Whatever the merits of the HEW bclicf about first amendment rights and Title IX, the Department has cffectively prevented the adjudication of those rights by deciding not to issue regulations. If the complainants take the Department to court the issue will be not whether regulating textbooks violates the first ainendment but rather whether the Department is obligated by Title IX to promulgate regulations about every aspect of education. HEW has put itself in the position of deciding the constitutionality of regulation seemingly authorized by Congress, a function more appropriately left to the judiciary in this particular setting. ${ }^{113}$

\section{B. State Level}

Pursuant to California legislation forbidding the use of textbooks which treat woinen as inferior, ${ }^{114}$ the California Curriculum Commission appointed a Legal and Factual Analysis Committee to review submissions of textbooks for the current adoption. ${ }^{116}$ The Committee met three times last fall, reviewed between 6000 and 7000 books and made a report to the Commission. ${ }^{116}$ The publishers werc informed of the Committee's criticisms and suggested changes but were also told that making the changes would not guarantec adoption since the textbooks had yet to be evaluated for educational value. ${ }^{117}$ The books were then reviewed by the Curriculum Commission itself. The Commission held meetings in March about the toxtbooks but was primarily concerned with the "rcadability" and "learnability" of the books. That is, the Commission wanted to know

112. Jacobs, supra note 69.

113. It seems that if HEW were concerned about the constitutionality of regulating textbook content, the fastest and surest way of resolving the issue would be to promulgate regulations and attempt to enforce them immediately. That way, those affected by the regulations could sue on the alleged first amendment claims and present the issues to the courts for determination. Instead, the Department is using first amendment questions, real or imagined, to keep the issues out of the courts and avoid a "definitive" decision on the matter.

114. Cal. EDuc. CoDe $\S \S 9240,9243$ (West Supp. 1973).

115. Legal and Factual Analysis Committee of the Curriculum Development and Supplemental Materials Commission (California), Report (Nov. 2, 1973).

116. Id. D. Ushio, Legal and Factual Analysis Committee of the Curriculum Development and Supplemental Materials Commission (California), Minority Position Paper (Nov. 29, 1973). Interview with Nancy Ward, member of the Legal and Factual Analysis Committce, in Oakland, Ca., Feb. 20, 1974.

117. Interview with Nancy Ward, supra note 116. 
which books they should use to get the highest reading scores on standard tests. ${ }^{118}$

That the Commission has made nothing more than a gesture in the direction of eliminating sex discrimination seems to be a fair conclusion based on the way it went about analyzing the submissions on their content. It had the Committee meet only three times to evaluate nearly 6000 books; members of the Committee had little advance notice of meetings and insufficient time to consult with each other. Their part in the evaluation process ended before any decisions were made and without the Committee being able to comment on pubhshers' proposed revisions. ${ }^{110}$

The Commission as a whole was reportedly unsympathetic to changing the content of the books to eliminate sexism; they were interested in more successful teaching of reading. ${ }^{120}$ One suspects that this means they were imterested in more successful learning of reading by boys, that they as educators share many of the attitudes about girls and schools discussed above and feel that girls already "overachieve" in elementary school anyway. It appears, in any case, that the Commission was willing to accept token changes in the content as comphance with the law and to use as an excuse where one was needed, that the publishers have not had enough time to make the changes. ${ }^{121}$ This excuse can be taken as true only if one is willing to ignore, as publishers have done, the efforts of the National Organization for Women and other feminist groups during the last few years to work with pubhishers on improving the treatment of females im textbooks. ${ }^{122}$

On June 13, 1974, the State Board of Education accepted the recommendations of the Curriculum Commission and adopted the recommended textbooks over the vehement objections of mimority and women's groups that the books fail to comply with the Education Code requirements. ${ }^{123}$ The current adoption covers only reading, English (i.e., grammar), hiterature, and dictionaries. Books for social studies, arithinetic, and science will be adopted in some other year. Books adopted now will be usable in public schools in California for five years. At the rate the California Curriculum Cominission and State Board of Education are going, significant change in textbook content will be very slow indeed.

118. This summary is based on my own attendance at the meetings.

119. Ushio, supra note 116; interview with Nancy Ward, supra note 116.

120. Interview with Nancy Ward, supra note 116; impressions from March meetings of the Curriculnm Commission.

121. Interview with Nancy Ward, supra note 116.

122. Id.

123. L.A. Times, June 14, 1974, at 3, col. 4. 
The Pennsylvania Department of Education appears to be taking a much more determined approach to the problem. In 1971 the Secretary of Education announced a commitment to elimination of sexism in education at all levels ${ }^{124}$ and this commitment was reaffirmed the following year. ${ }^{125}$ A Joint Task Force on Sexism in Education was appointed including members of the Department of Education, the Pennsylvania Human Relations Commission, and Pennsylvanians for Women's Rights. They issued a report in $1972^{126}$ which included an exposition of the problem, requirements for change, guidelines, and goals. The Secretary of Education then announced policies which schools were to follow and on which schools would be evaluated. These policies included elimination of sex-segregated and sex-stereotyped classes, programs, activities and courses of study, inclusion of feminist literature in school libraries and of favorable portrayals of women in nontraditional roles in instructional materials, including textbooks. ${ }^{127}$

Given high priority was the selection of textbooks and library inaterials which present a fair and realistic treatment of women to counteract traditional sex stereotypes found in the majority of curriculum materials. ${ }^{128}$ The Task Force Report sets out guidelines for the selection of such materials. ${ }^{128}$ Another priority was the compilation of a comprehensive annotated bibliography of books, periodicals, and nonprint materials which present a positive image of woinen. This bibliography would be distributed to librarians, teachers, and publishing companies "to familiarize them with standards for, and exanuples of, acceptable non-sexist curriculum and library materials."130

The report and the statements of the Secretary of Education are impressive. They deal with all aspects of the problem of sex stereotyping and sound very determined to eliminate it. Unfortunately, the first follow-up report of how these policies are being carried out shows little impact. ${ }^{131}$ Only 62 percent of the districts responded and 27 percent of these reported no efforts made. ${ }^{132}$ With regard to textbooks, only 90 districts (out of 311 reporting) had instructed

124. Joint Task Force, supra note 97, at 30A (Appendix A) (Memorandum from then Sec. of Educ., David Kurtzman, dated October 15, 1971).

125. Memoranda from the Pa. Sec. of Educ., supra note 97.

126. Joint Task Force, supra note 97.

127. Id. at 12-13; Memoranda from the Pa. Sec. of Educ., supra note 97.

128. Joint Task Force, supra note 97, at 12-13.

129. Id.

130. Id. at 13 (emphasis in original).

131. P. Stank, Summary Report on 1973 Survey of Local Policies Initiated in Education to Eliminate Sexism (Pa. Dep't of Educ. 1974).

132. Id. at 1 . 
teachers to evaluate the representation of women in textbooks. ${ }^{133}$ The Department has compiled an extensive bibliography, ${ }^{134}$ but most of the items are for high school and college. And, despite the priority given to curriculum and library materials, and apparent demands being made on publishers, it does not appear that Pennsylvania has yet refused to buy textbooks from publishers until the books are changed significantly.

\section{Local Level}

The Berkeley Public Schools, at the behest of a group of parents, teachers and other interested citizens, instituted a women's studies progrant in the fall of 1972. The purpose of the women's studies program is to overcome the sex stereotyping in the state adopted textbooks with supplementary materials showing nonsexist portrayals of both males and females and raising the issue of sex stereotyping for class discussions.

The program has one staff member, an experienced teacher. She has created a number of individual lessons and some curriculum umits about women or about sex discrimination. The materials mclude stories such as The Story of $X^{\mathbf{1 3 5}}$ about a child whose sex was kept secret and who had twice as much fun as the other children because it felt free to participate in both "male" and "female" activities; biographies of female historical figures; a umit in which the children research the anti-female bias of their textbooks and the media; and a unit about growing up female and inale in America. ${ }^{188}$ The materials include coverage of the women's moveinent of the 19th century and of minority women.

The director's own evaluation of the program is that suppleinentary materials are not enough. ${ }^{137}$ She says that the impact of the texts and the reliance of teachers on textbooks are both so great that supplementation is entirely inadequate. She has found that teachers are reluctant to use the materials she provides, especially the larger umits; some even resist the single lessons. Even when the materials are used, they are ineffective in overcoming the textbooks' view of sex roles.

Another problem the program has is the constant threat of dissolution. There is always pressure to eliminate as inany nonteaching

133. Id., Table 3.

134. Pa. Dep't of Educ., Images of Women, A Bibliograplyy of Feminist Resources for Pennsylvania Schools (Nov. 1973).

135. By Lois Gould, originally published in 1 Ms., No. 6, 74 (Dec. 1972).

136. These materials are available from the Berkeley Women's Studies Program.

137. Interview with Susan Bement, Director of Women's Studies, Berkeley Public Schools, February 21, 1974. 
positions as possible and the attainment of sex equality is not considered a priority in the school system. Some proponents of the existing ethnic studies programs, including their directors, have been extremely hostile to the women's studies program. Much of the focus of the women's studies program during the 1973-74 academic ycar (the second of its existence) was to coordinate with the ethnic studies programs in order to develop some solidarity with them. Nevertheless, ethnic equality continues to be a higher priority in the Berkeley public schools than sex equality.

The school system in Kalamazoo, Michigan, established a Committee to Study Sex Discrimination. ${ }^{138}$ The Committee recommended agaimst the adoption of the most recent Houghton-Mifflin series of readers (1971) even though the school superintendent said that it was the best reading program available and was less biased than the old ones. ${ }^{139}$ The Committee responded that the series was still not good enough and subsequently filed a complaint with HEW about the adoption..$^{140}$

In addition to reviewing textbooks for possible adoption the Committee revised teacher's manuals and suggested ways for teachers to supplement textbooks. ${ }^{141}$ Much of the content of the manual is tied to the children's books which were not changed so the revisions in the manual were somewhat limited. The main kind of change was in the directions to teachers about what to say or write on the board. The Committee changed things like "Dad is digging up the little tree" to "Mother is digging up the little tree" and "Mother is cutting up apples for us" to "Dad is cutting up apples for us."142 They added questions for teachers to ask the children to raise the issue of sex bias in the books. And they are also providing the teachers with lists of poems and stories about females. ${ }^{143}$

Although the Committee no longer lias official status, it continues as a citizens' group. Further work is planned concentrating on developing other kinds of materials to supplement the reading series such as movies and film strips, posters and bulletin board materials with non-stereotyped content. The Committee has also received a

138. Dietrich statement, supra note 26 , at 463 . But the Committee is now disbanded as an official body. See Ahlum, Kalamazoo: A Model for Change, 2 Women's Studies NewsletTer, No. 1, 1 (Winter 1974).

139. Dietrich statement, supra note 26 , at 464 .

140. Id.; Jacobs, supra note 69; see text accompanying notes 112-13 supra.

141. Dietrich statement, supra note 26 , at 467-68. They have published their revisions as Recommendations for Eliminating Sex Discrimination in the Reading Program (1973), available from the Kalamazoo Public Scliools.

142. Dietrich statement, supra note 26 , at 468.

143. Id. 
promise from Houghton-Mifflin for support of supplemental material development and an indication that the publisher will treat Kalamazoo as a pilot project for the study of sex discrimination in textbooks. ${ }^{144}$ The value of this commitment is questionable; it is far from a straight forward determination to eliminate sex bias from the books published by Houghton-Mifflin.

\section{Private Groups}

A number of private groups have begun developing materials similar to those being developed in Berkeley and Kalamazoo but in some cases on a larger scale and as alternatives rather than as supplements.

A privately funded group called Change for Children began recently in San Francisco and provides among other things an entire library of books which could be used instead of the readers now in use. While they are not part of a "reading program" such as those produced by publishers and adopted by state curriculum commissions, they are children's stories which children can and do read and they have the advantage of treating males and females as equals.

Change for Children has also begun an in-service training program for teachers in the San Francisco public schools. Eight teachers participated in the first eight-week session, held last fall. Another series is being offered this spring. One of the staff members of Change for Children reported that the in-service program would not have been accepted by the school board without the firm support of Fern Kelly, the director of in-service training in San Francisco, and that, although they are allowed to provide the program, the schools do not reimburse them for it. This staff member commented on the importance accorded sex equality in San Francisco schools by comparison with Berkeley: im Berkeley the elimination of sex discrimination is not considered a priority; in San Francisco the existence of the problem is barely acknowledged. ${ }^{145}$

The Change for Children library includes materials produced by established publishers and by noncommercial groups or by the authors themselves. These groups include the National Education Association, which has developed a number of curriculum models; ${ }^{146}$ the Feminist Press, which has developed some curriculum models and has published a number of nonsexist books for children,; ${ }^{147} \mathrm{KNOW}$, Inc.,

144. Id.

145. Interview with Irene Kane of Change for Children, in San Francisco, Ca., March 5, 1974.

146. EDUCATION For SURVIVAL, supra note 99.

147. Ahlum \& Fralley, supra note 100. 
a publisher specializing in women's studies materials for all educational levels; ${ }^{148}$ the N.O.W. Education Task Force and various other N.O.W. branches which have developed critiques of the existing materials as well as alternatives. ${ }^{149}$ At the moment these groups provide resources for the few supplementation programs like Berkeley and Kalamazoo, but for the most part are not reaching children or those in charge of what does reach children.

\section{III}

The continuing use of sex-biased textbooks in the public schools is currently justified on the basis that these books are the best "educationally" of those available. ${ }^{150}$ There are alternatives, however, and their use as supplementary materials is totally madequate to overcome the effects of the textbooks. It seems unlikely, as well, that there will be many school districts willing to imvest in women's studies programs or many teachers willing to use materials which demand more imagination and effort by teachers when there are textbooks at hand.

The passage of a statute stating that textbooks must not be biased is not having the effect of inducing publishers to produce nonsexist books. The experience of the members of the Legal and Factual Analysis Committee in California ${ }^{151}$ indicates that the statute is not enough. The Commission and the State Board of Education appear to be as resistant to eradicating sex bias as are the publishers, and until schools refuse to purchase biased books, publishers will not find it necessary to produce unbiased ones.

The adoption of textbooks is at least as much a political as a professional decision. Educators claim to be seeking the most "readable" and "learnable" materials, yet their notions of what is "learnable" are of questionable validity and imclude blatant anti-female bias. ${ }^{152}$ The choices made so far have reflected the basic assumption that boys and girls have different educational needs; that they are not only being prepared for different, mutually exclusive roles in adulthood but also require different kinds of materials in order to learn. The use of such a behief cannot be justified as professional judgment. There is no evidence that girls are innately limited to stereotyped roles and interests. The statement that one can teach boys but not

148. Id.

149. Id.; Change for Children publishes its own bibliography called Anything You Want to Be, a Bibliography of Nonracist Nonsexist Picture Books and Young Fiction (1974).

150. Dietrich statement, supra note 26 , at 464.

151. Legal and Factual Analysis Committee of the Curriculum Development and Supplemental Materials Commission (California), supra note 115.

152. Waite, Blom, Zimet \& Edge, supra note 8. 
girls about nuclear fission at an early age because girls would not respond to $\mathrm{it}^{153}$ is nothing more than a display of gross prejudice. And because boys and girls are subject to sex role socialization from birth, it is currently impossible to make any determination of what innate differences there might be between boys and girls in intellectual functioning. ${ }^{154}$

Curriculum Commissioners, being educators and being infused with these same attitudes about "learnability," cannot be relied on to require sex-neutrality in textbooks. Althougl the bids for books made mention of expanding the horizons of the children, showing more than "existing" behavior and having more than minimal representation of women in history books, ${ }^{155}$ these specifications barely scratch the surface of the problem. They even appear to be based on a behef that the behavior portrayed in books now is an accurate representation of reality despite the fact that the books show nothing but one-dimensional stereotypes of females and would have children believe that there is no conflict, no divorce, no politics-nothing but middle-class blandness and banality in the world. ${ }^{156}$ The Kalamazoo, Michigan, school board was also willing to adopt a series of books which were the best "educationally" even though containing only token improvement in the treatinent of females. ${ }^{157}$ Therefore, it is necessary to make it clear not only to publishers but also to textbook adopters that sex-biased books can no longer be used in public schools.

The fear of being without textbooks may be the leverage with which to force significant changes in the books. A suit to enjoin the adoption or use of particular books which curriculum commissions or school boards are willing to accept, leaving thein with no books at all until they come up with nonsexist ones, would force thein to take the problem more seriously than they apparently take it now. ${ }^{158}$

153. Lyles, supra note 84 , at 41 . This statement has been refuted by Torrance, supra note 43 , at 111-13.

154. Weisstein, supra note 64 , at 144.

155. Interview with Nancy Ward, supra note 116.

156. This is the impression one would get of the world from reading current textbooks. See Kidd, supra note 50 .

157. Dietrich statement, supra note 26, at 464.

158. Apparently there are those who would argue that an injunction against the use of a particular set of textbooks would constitute censorship in violation of the first amendment. See text accompanying notes 102-113 supra. In fact, however, such an injunction would only serve to keep a school board or curriculum commission within constitutional requirements of equahty as it carries out its function of providing edueation. The books could still be published and even used in school libraries which would presumably also contain nonsexist and preferably overtly feminist books as well from which the children would be free to choose for their own reading. The court order would be directed not at what the children will be allowed to read but at the curriculum which children are required not only to read but to absorb and internalize; that curriculum $m$ ust be chosen in accordance with constitutional requirements. 
Such a suit would be based on constitutional objections in two lines of argument. Sex stereotyping denies girls equal protection of the laws by providing them with a substantially different and inferior education than is provided to boys. Sex stereotyping denies both boys and girls basic personal liberty to develop as imdividuals, not to be required to conform to standard personality types; the denial is more destructive to girls since boys are encouraged to have a positive selfimage and an expansive view of their own potential while girls are taught that they are inferior, are given a negative self-image and a limited view of their own potential.

\section{A. Equal Protection}

The inferior education provided for girls as compared with boys violates the equal protection clause. Under the traditional rational basis standard, differential treatment of any classes "must be reasonable, not arbitrary, and must rest upon solne ground of difference having a fair and substantial relation to the objeot" sought to be achieved. ${ }^{150}$ The purpose of the public schools is, presumably, to enable all children to become, in adulthood, contributing members of society. A classification which limits the fulfilment of that purpose to, at best, half the population can lrardly be considered rationally related to the object sought to be achieved. The distinctions between males and females defeat the purpose by limiting female children to the role of appendages of males, a role perhaps consistent with traditional notions of femininity but antithetical to the goal of universal education.

The schools are operating on the basis of a presumption that all female children, simply because of their sex, are limited to the traditional female role; the curriculum has the effect of perpetuating that presumption. ${ }^{160}$ This classification is comparable to the differential availability of dependent's allowances to male and female service personnel, ${ }^{161}$ the conclusive presumption that unmarried fathers are unfit parents, ${ }^{162}$ the statutory preference for male administrators of dece-

159. Royster Guano Co. v. Virginia, 253 U.S. 412, 415 (1920).

160. The suggestion has been made that there have to be some distinctions made among children or it would be necessary to train all children for everything. Dornbush, Afterword to The Development of Sex Differences 204, 209-10 (E. Maccoby ed. 1966). The rationale for distinguishing along sex lines is that since girls are destined to be wives and mothers they should be educated for those roles. Boys, of course, are equally likely to become husbands and fathers, but no one feels any need to educate them for those roles at all, much less to the exclusion of all else. There is no explanation other than tradition and male convenience why girls must have such limited destinies. Distinctions based on demonstrated interest or ability rather than sex are certainly more consistent with traditional notions of rationality.

161. Frontiero v. Richardson, 411 U.S. 677 (1973).

162. Stanley v. Illinois, 405 U.S. 645 (1972). 
dents' estates, ${ }^{163}$ and the presumption that pregnant teachers cannot work beyond an early date in their pregnancy. ${ }^{164}$ In each of these cases the belief in the umiversal applicability of the traditional female role provided the basis for limiting the exercise of certain rights or the availability of certain benefits on the basis of that stereotype. In each case the Court invalidated the classification either as a denial of equal protection or as a demal of due process through the use of conclusive presumptions although, as Mr. Justice Powell has suggested, ${ }^{105}$ the latter may be merely a mask for the former.

The schools have established a classification based on this presumption, a presumption which is not universally true and, though some believe that the characteristics on which it is based are innate in all females, the presumption is not susceptible of proof. The effect of this classification is to provide female children with an education inferior to that provided male children.

It has also been argued that sex sliould be treated as a suspect classification. Four members of the Court have already lield it to be such. ${ }^{100}$ Under this analysis, the differential treatınent of males and females in public school textbooks would be subject to strict scrutiny, and the state would have to show a compelling interest in continuing the dichotomy of treatment. The only interest the state miglit reasonably advance as compelling would be a claim that boys will not be able to learn to read from books which do not make a sharp distinction in sex roles, a theory advanced by some educators. ${ }^{167}$ If this were true, it would still be questionable whether the state may choose to improve the academic experience for boys at the expense of teaching feinales that they are inferior. The state's position would amount to arguing that male children are academically in-

163. Reed v. Reed, 404 U.S. 71 (1971).

164. Cleveland Bd. of Education v. LaFleur, 94 S. Ct. 791 (1974).

165. Id. at 802 (Powell, J., concurring).

166. Frontiero v. Richardson, 411 U.S. 677,688 (1973). The argument that sex is a suspect classification has been made many times and adopted not only by 4 members of the Court in Frontiero but also by a majority of the California Supreme Court in Sail'er Inn, Inc. v. Kirby, 5 Cal. 3d 1, 485 P.2d 529, 95 Cal. Rptr. 329 (1971). See Crozier, Constitutionality of Discrimination Based on Sex, 15 B.U.L. Rev. 723 (1935); Note, Sex, Discrimination, and the Constitution, 2 Stan. L. Rev. 691 (1950); Murray \& Eastwood, Jane Crow and the Law: Sex Discrimination and Title VII, 34 GEo. WASH. L. Rev. 232 (1965); Seidenberg, The Submissive Majority: Modern Trends in the Law Concerning Women's Rights, 55 CoRnell L. REv. 262 (1970). The analogy between race and sex has also been made by sociologists like Gunnar Myrdal in his famous $A p$ pendix $V$, in MYrdal, AN AmErican Dilemma 1073-78 (1944), and Helen Hacker in Women as a Minority Group, 30 Soctal ForCEs 60 (1950).

But cf. Gedulding v. Aiello, 42 U.S.L.W. 4905 (avoiding the issue by holding that pregnancy discrimination is not sex discrimination).

167. Waite, Blom, Zimet \& Edge, supra note 8. 
ferior and that the state must compensate for that inferiority. Surely it would be constitutionally obligated to find some means of teaching boys which did not require destruction of girls.

The state would also be under a leavy burden to prove that this learning theory has any validity. The educators who advanced it criticized the books for being "feminine" and for lacking sex role differentiation, ${ }^{168}$ although other reviewers of the same books found them to be totally male-dominated and anti-female. ${ }^{169}$ The criticism of "femininity" was based on the characterization of the books as "pollyannish"170 and the fact that the children in the books were very young, younger than the children by whom the books were intended to be read. ${ }^{171}$ This is the educators' definition of femininity: infantile and pseudo-cheerful. They lrave revealed their own belief in female inferiority but they have proven nothing about why Johnny can't read. Since there is no valid empirical data supporting the widespread belief in either female inferiority or the "feminine" sources of male learning difficulties, the unsupported theories can hardly be considered compelling. In fact, they are the very kind of justifications for inequality which inake classifications suspect; the state might as well say that it must teach that blacks are inferior to whites because educators believe they are and claim that white children will not be able to learn to read from books which show blacks and whites as equals.

The objection has been raised that the public does not want the stereotyping of females eliminated from textbooks, ${ }^{172}$ but this argument holds even less weight than "Iearnability" considerations in the face of constitutional and statutory requirements ${ }^{173}$ of equality. Parents are free to teach their children sex role stereotypes just as they can teach them to pray or to hate ethnic minorities. But the government must not do so.

\section{B. Personal Liberty}

The right of privacy is an elusive one. It was enunciated by Justice Brandeis in his famous wiretap dissent ${ }^{174}$ as the right to be free of governmental intrusion into one's home. Brandeis raised the

168. Id.

169. Key, supra note 76 at 16.

170. Waite, Blom, Zimet \& Edge, supra note 8, at 367 .

171. Id. In another article based on this same study, the authors say that "real life with positive emotions" is associated with girl activity and that the stories can also be called pollyanna stories. Blom, Waite, \& Zimet, Content of First-grade Reading Books, 21 THE READING TEACHER 317, 318-19 (1968).

172. Interview with Nancy Ward, supra note 116.

173. The California statutory provision, note 96 supra, arguably does no more than restate what the fourteenth amendment already requires.

174. Olmstead v. United States, 277 U.S. 438 (1928). 
right of privacy in a fourth amendment context:175 it now appears also under the first, ${ }^{178}$ fifth $^{177}$ and ninth ${ }^{178}$ amendments. It is said to be "broad enough to encompass a woman's decision whether or not to terminate her pregnancy." 179 Mr. Justice Douglas has defined it as being, in part, the right to autonomous control over the development and expression of one's intellect, interests, tastes, and personality. ${ }^{180}$

To the extent that the public schools interfere with this right by controlling and limiting a child's autonomy in these areas, the schools are violating a fundamental right. The Court has ruled that children do not leave their rights at the schoolhouse door when they enter. ${ }^{181}$ Yet the current curriculum materials deny girls this fundamental right by presenting and validating the stereotyped view of females. ${ }^{182}$

In an analogous and probably related situation, the circuit courts have divided over whether public schools can control the hair length of male students. ${ }^{183}$ The Supreme Court has consistently denied certiorari, apparently because some Justices just couldn't take the issue seriously. ${ }^{184}$ The real issue in the liair-length cases seems to be whether and to what extent the schools can enforce conformity in personal appearance, particularly based on sex stereotyped standards. Presumably the Court will consider more serious the wholesale indoctrination of half the population to believe in their own inferiority. But

175. Other fourth amendment privacy cases include Terry v. Ohio, 392 U.S. 1 (1968) and Katz v. United States, 389 U.S. 347 (1967) (overruling the Olmstead decision from which Justice Brandeis had dissented).

176. Stanley v. Georgia, 394 U.S. 557 (1969).

177. Rochin v. California, 342 U.S. 165 (1952).

178. Griswold v. Connecticut, 381 U.S. 479 (1965). Pierce v. Society of Sisters, 268 U.S. 510 (1925), and Meyer v. Nebraska, 262 U.S. 390 (1923), are also often cited as establishing a right of privacy.

179. Roe v. Wade, 410 U.S. 113,153 (1973).

180. Doe v. Bolton, 410 U.S. 179, 211 (1973) (Douglas, J., concurring).

181. Tinker v. Des Moines School Dist., 393 U.S. 503, 506 (1969).

182. Boys are also limited by stereotyping; they are discouraged from admitting or displaying their emotions and so on; but they are given a positive self-image and a broad range of choices for their futures which girls are demied, and they are encouraged to prepare themselves to be economically self-sufficient while girls are taught to be economically dependent on men.

183. For the students: Massie v. Henry, 455 F.2d 779 (4th Cir. 1972); Bishop v. Colaw, 450 F.2d 1069 (8th Cir. 1971); Richards v. Thurston, 424 F.2d 1281 (1st Cir. 1970); Breen v. Kahl, 419 F.2d 1034 (7th Cir. 1969), cert. denied, 398 U.S. 937 (1970). For the schools: Freeman v. Flake, 448 F.2d 258 (10th Cir. 1971), cert. denied, 405 U.S. 1032 (1972); King v. Saddleback Junior College Dist., 445 F.2d 932 (9th Cir. 1971), cert. denied, 404 U.S. 979 (1971); Jackson v. Dorrier, 424 F.2d 213 (6th Cir. 1970), cert. denied, 400 U.S. 850 (1971). There are 37 cases cited in Note, 84 HARV. L. REv. 1702, 1703 n.4 (1971).

184. See Justice Black's opinion denying a motion to vacate a stay of imjunction in Karr v. Schmidt, 401 U.S. 1201 (1971). 
the schools are doing the same thing both when they select textbooks and when they decide how long boys may wear their hair. They are enforcing sex role conformity which has no apparent relation to education. One circuit judge commented (naively perhaps):

Our institutions do not rely on submerging individual personality in order to create an "idealized" citizen. The abhorence of such treatment steins froin the enlightened philosophy that school children must be given every feasible opportunity to grow in independence, to develop their own individualities and to initiate and thrive on creative thought. ${ }^{185}$

It may be that our public schools do rely on submerging the individual, particularly the individual female. But if so, they are depriving girls of a fundamental right. Although a woman may choose to use birth control whether she is married ${ }^{188}$ or single ${ }^{187}$ or to have an abortion $^{188}$ without state interference, she is demed the opportunity to develop an image of herself as anything other than a wife and mother. In some ways these established rights inay mean very little if women are so indoctrinated in public school that they are not really free to exercise them.

The female stereotype is accompamied by its male stereotype; boys are also denied, to some degree, the right to develop their individualities. ${ }^{189}$ But the restrictions placed on boys are much less than those placed on girls. The possibility of exercising one's fundamental right is denied unequally, raising an additional equal protection problem.

\section{CONCLUSION}

Given constitutional requirements of equality for all children as children, not as males and females, the obligation of those choosing textbooks for use in public scliools is to choose nondiscriminatory textbooks even though there might be some sex-biased books which are considered more "learnable."

A court might share the concern that enjoining the use of discriminatory books would leave teachers with nothing to teach from, but with the bibliographies of nuaterials available as alternatives it seems

185. Bishop v. Colaw, 450 F.2d 1069, 1078 (8th Cir. 1971) (Lay, concurring).

186. Griswold v. Connecticut, 381 U.S. 479 (1965).

187. Eisenstadt v. Baird, 405 U.S. 438 (1972).

188. Roe v. Wade, 410 U.S. 113 (1973); Doe v. Bolton, 410 U.S. 179 (1973).

189. See TORRANCE, supra note 43 , for an argument that emphasis on sex roles inhibits the development of creative abilities in both male and female children. An argument can be made that by emphasizing sex roles and thus inhibiting creativity in children the schools are failing to carry out one of their primary tasks, that of fostering intellectual development. 
clear that this is not a real problem. There might be no textbooks, a situation which might put a burden on teachers to be more imaginative in finding things for children to read and do. But there would certainly be stories and projects which could be used. Although there have always been textbooks, there are those learning theorists who believe that textbooks are stultifying and fail to develop cognitive and creative abilities. ${ }^{100}$ The reliance on textbooks may be misplaced. At least, there is controversy about it, and a court may properly require a school district to use textbooks with constitutionally acceptable conent or not use textbooks at all. Materials used as substitutes would, of course, also be subject to judicial scrutiny concerning their treatment of females.

The schools have so far engaged in serious political indoctrination in favor of the status quo in general ${ }^{191}$ and the subordination of women in particular. Perhaps the schools cannot legitimately indoctrinate children with militant feminism either, but given the historical and continuing practice of teaching female inferiority, the schools ought to be placed under a specal obligation to compensate for the past and current wrong, to teach equality until it is achieved and no longer needs to be inculcated.

Carol Amyx

190. Telephone interview with Nancy Pietrafesa, teacher in the Oakland (California) Public Schools now participating in an experimental early childhood education program. Ms. Pietrafesa reports that many experienced teachers, extrapolating from their own observations and from the works of Piaget and Chomsky in particular, have come to view textbooks as disincentives to reading. She suggests that children should be shown that reading is a constant, everyday activity, that wherever they rest their eyes they will be reading something (street signs, the cereal package), and that they can learn to read from all aspects of their lives which are more interesting than the readers and much more compelling to the children. See also H. KoHL, READING, How To (1973); E. Torrance, Encouraging CREativiTy IN THE Classroom 81 (1970) (saying that one must go beyond textbooks in order to develop children's intellectual capacities); Fischle, The Day They Locked Up the Textbooks, 52 NAT'L ElEMENTARY PrINCIPAL No. 3, 96 (Nov. 1972).

191. Kidd, supra note 50. 